\title{
Through Other Continents
}


This page intentionally left blank 


\title{
Through Other Continents
}

\section{AMERICAN LITERATURE ACROSS DEEP TIME}

\author{
Wai Chee Dimock
}


Copyright $\odot 2006$ by Princeton University Press

Published by Princeton University Press, 41 William Street, Princeton, New Jersey 08540

In the United Kingdom: Princeton University Press, 6 Oxford Street, Woodstock, Oxfordshire OX20 1TW

All Rights Reserved

Second printing, and first paperback printing, 2009

Paperback ISBN: 978-0-691-11450-7

The Library of Congress has cataloged the cloth edition of this book as follows

Dimock, Wai-chee, 1953-

Through other continents : American literature across deep time/Wai Chee Dimock.

p. $\mathrm{cm}$.

Includes bibliographical references and index.

ISBN-13: 978-0-691-11449-1 (cloth : alk. paper)

ISBN-10: 0-691-11449-8 (cloth : alk. paper)

1. American literature-History and criticism. 2. American literature-Foreign

influences. 3. Globalization in literature. 4. Literature, Comparative-American and Ancient. 5. Literature, Comparative-Ancient and American. 6. Influence (Literary, artistic, etc.) I. Title.

PS157 .D56 2006

$810.9-\mathrm{dc} 22 \quad 2005057723$

British Library Cataloging-in-Publication Data is available

This book has been composed in Sabon

Printed on acid-free paper. $\infty$

press.princeton.edu

Printed in the United States of America

$\begin{array}{lllllllll}10 & 9 & 8 & 7 & 6 & 5 & 4 & 3 & 2\end{array}$ 
For GD and Beatrice 
This page intentionally left blank 